\title{
Anatomic Variants of Foramen Ovale and Spinosum in Human Skulls
}

\author{
Variantes Anatómicas de los Forámenes Oval y Espinoso en Cráneos Humanos
}

Aaijaz Ahmed Khan; Mohd Asnizam Asari \& Asma Hassan

KHAN, A. A.; ASARI, M. A. \& HASSAN, A. Anatomic variants of foramen ovale and spinosum in human skulls. Int. J. Morphol., 30(2):445-449, 2012.

SUMMARY: Foramen ovale and spinosum are important foramina of the greater wing of the sphenoid. Normal variations in their shapes and sizes are quite common and widely studied. In the present study, conducted in the Department of Anatomy of School of Medical Sciences, Universiti Sains Malaysia, 25 dried human skulls were examined for anatomic variations of the foramina of the greater wing of the sphenoid. During the study, we noticed anatomic variations of the foramen ovale and spinosum. In one skull, there was an abnormally large and irregular foramen ovale which was confluent with the foramen spinosum. In the second skull, the foramen spinosum was absent on the left side and in the 3rd skull it was duplicated on the right side. These variations are very rare and may be of clinical and anatomical significance to neurosurgeons and physicians particularly in cases of trigeminal neuralgia, diagnostic detection of vascular tumors and aneurysm.

KEY WORDS: Variation; Skull; Foramen; Sphenoid; Foramen ovale; Foramen spinosum.

\section{INTRODUCTION}

Foramen ovale and spinosum are important foramina of the middle cranial fossa. Foramen ovale is situated in the greater wing of the sphenoid bone, posterior to the foramen rotundum and lateral to the lingula and posterior end of the carotid groove (Sondheimer, 1971). It gives passage to the mandibular nerve, accessory meningeal artery and lesser petrossal nerve. In majority of cases, it is oval in shape but as compare to other foramina of the skull, its shape and size is quite variable. It has practical significance to both neurosurgical and functional cranial neuroanatomy as it provides transcutaneous approaches to the skull base especially in cases of trigeminal neuralgia, as the Gasserion ganglion can be approached through it (Kaplan et al., 2007; Reymond et al., 2005).

Foramen spinosum is a small circular foramen located in the greater wing of the sphenoid near or at the root of spine of sphenoid, posterolateral to foramen ovale. It transmits middle meningeal artery to the middle cranial fossa (Chaurasia, 2004; Sinnatamby, 1999; Standring, 2005). Several previous studies reported the normal variations in its shape and size. Foramen spinosum occurred as a permanent element in majority of cases, but in $0.4 \%$ of cases, it may be absent altogether when middle meningeal artery arises from the ophthalmic artery. Sometime the ossification of ligaments (ligaments of Civinini and Hyrtl) near the foramen ovale divides it into 2 or 3 compartments. In some other cases, foramen spinosum may be duplicated.

While studying the foramina of the skulls in the greater wing of sphenoid, we noticed interesting anatomic variations of foramen ovale and spinosum in three of the skulls. These variations are very rare therefore we decided to report these cases.

\section{MATERIAL AND METHOD}

Twenty-five dried human skulls available in the Department of Anatomy, School of Medical Sciences, Universiti Sains Malaysia were included in the present study. For each skull, features and anatomic variations of the foramina at the greater wing of sphenoid were carefully inspected and noted. In addition, size of foramen ovale was measured by vernier caliper and simple measuring scale. The photographs were taken by Sony digital camera. 


\section{RESULTS}

In one skull (Figs. 1 and 2), a large irregular foramen was observed on the right side of the skull. It measured 12 $\mathrm{mm}$ in length and $6 \mathrm{~mm}$ in width with irregular margins. Two large bony spicules, one from its lateral and the other one from its posterior margin, divided it into two incomplete compartments; an anterior foramen ovale and a posterior foramen spinosum. Similarly, another spicule was projecting posterolaterally from its medial margin.

In the second skull (Figs. 3 and 4) we noticed that foramen spinosum was absent on the left side and the foramen ovale was semilunar in shape and smaller in size than the right side foramen ovale. The grooves for meningeal vessels were clearly visible. On the right side, both the foramen ovale and spinosum were normal.

In the third skull (Figs. 5 and 6) we found a duplicated foramen spinosum on the right side with anterior and posterior compartments. Both of the compartments were roughly oval in shape and almost equal in size. A bony bar which divided it into two was more clearly visible from the base of the skull.

\section{DISCUSSION}

Foramen ovale differs in shape and size throughout the natural life. The earliest perfect ring-shaped formation of the foramen ovale was observed in the 7th fetal month and the latest at 3 years after birth (Yanagi, 1987). Incidence of variations in the shape and size of foramen ovale varies. The appearance of the various bony outgrowths of the foramen ovale like spine, spur, tubercle, bony plate etc indicate bony overgrowth during its developmental process between its first appearance and perfect ring formation. In the present study, in one of the skull we found a large irregular confluent foramen ovale and spinosum which was measuring about $12 \mathrm{~mm}$ antero-posteriorly and $6 \mathrm{~mm}$ transversely. These two foramina were incompletely separated from each other by two bony spicules, which were projecting from its lateral and posterior margins respectively. Ray et al. (2005) reported

Fig. 3. Photograph of the middle cranial fossa showing absence of foramen spinosum on the left side. OC - Optic Canal, ACP-Anterior Clinoid Process, RFR - Right Foramen Rotundum, RFO - Right Foramen Ovale, RFS - Right Foramen Spinosum, LFO - Left Foramen Ovale, LFR - Left Foramen Rotundum, HF - Hypophyseal Fossa, ICC - Internal opening of Carotid Canal, FM - Foramen Magnum.

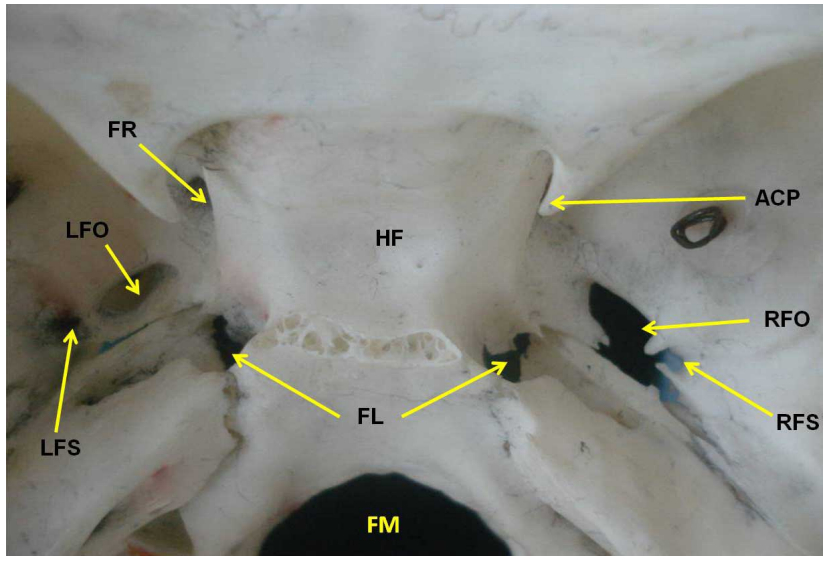

Fig. 1. Photograph of the middle cranial fossa showing confluent foramen ovale and spinosum on the right side. HF - Hypophyseal Fossa, ACP - Anterior Clinoid Process, RFO - Right Foramen Ovale, RFS Right Foramen Spinosum, FL - Foramen lacerum, LFS - Left Foramen Spinosum, LFO - Left Foramen Ovale, FR - Foramen Rotundum, FM - Foramen Magnum.

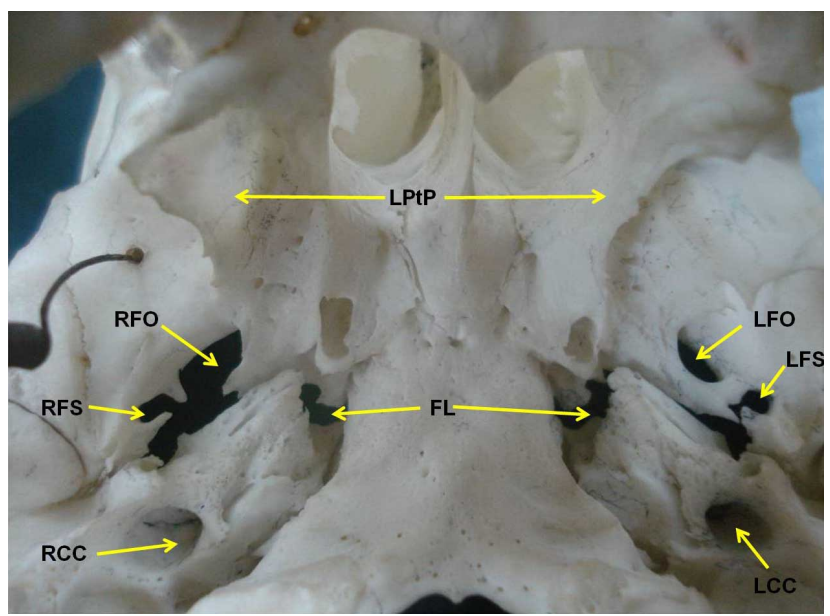

Fig. 2. Photograph of the base of the skull showing confluent foramen ovale and spinosum foramen on the right side. LPtP - Lateral Pterygoid Plate, RFO - Right Foramen Ovale, RFS - Right Foramen Spinosum, RCC - Right Carotid Canal, LCC - Left Carotid Canal, LFS - Left Foramen Spinosum, LFO - Left Foramen Ovale, FL - Foramen lacerum.

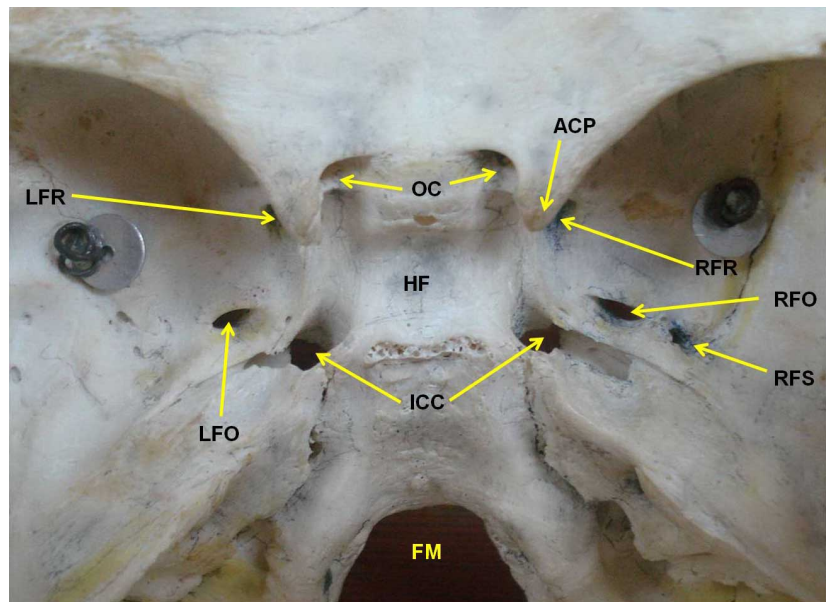




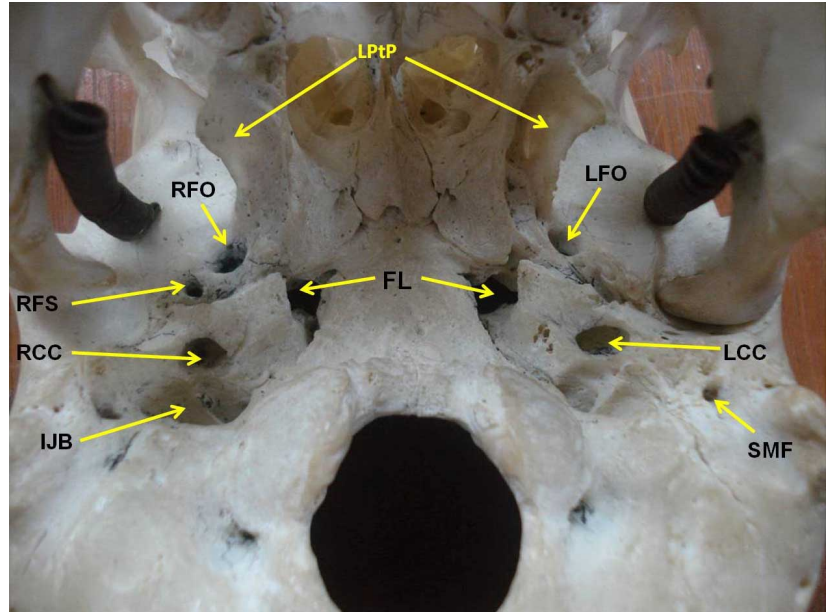

Fig. 4 - Photograph of the base of the skull showing the absence of foramen spinosum on the left side. LPtP - Lateral Pterygoid Plate, Vr Vomer, LFO -Left Foramen Ovale, LCC - Left Carotid Canal, SMF Stylomastoid Foramen, IJB - Internal Jugular Bulb, RCC - Right Carotid Canal, RFS - Right Foramen Spinosum, RFO - Right Foramen Ovale, FL - Foramen Lacerum.

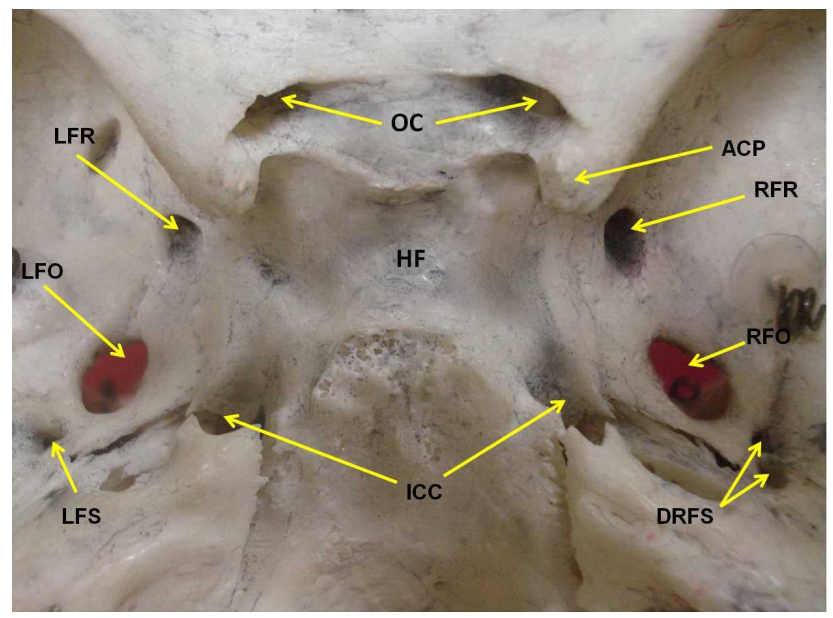

Fig. 5. Photograph of the middle cranial fossa showing duplicated foramen spinosum on the right side. OC - Optic Canal, HF - Hypophyseal Fossa, ACP - Anterior Clinoid Process, RFR -Right Foramen Rotundum, RFO Right Foramen Ovale, DRFS - Duplicated Right Foramen Spinosum, ICC - Internal opening of Carotid Canal, LFS - Left Foramen Spinosum, LFO - Left Foramen Ovale, LFR - Left Foramen Rotundum.

variant foramen ovale in $24.2 \%$ of their cases. According to them, mean length and width of foramen ovale was $7.46 \pm$ $1.41 \mathrm{~mm}$ and $3.21 \pm 1.02 \mathrm{~mm}$ respectively on right side and $7.01 \pm 1.41 \mathrm{~mm}$ and $3.29 \pm 0.85 \mathrm{~mm}$ respectively on left side. Similar dimensions were reported by Yanagi.

Tubbs et al. (2009), in their study on ossification of ligaments near the foramen ovale revealed that

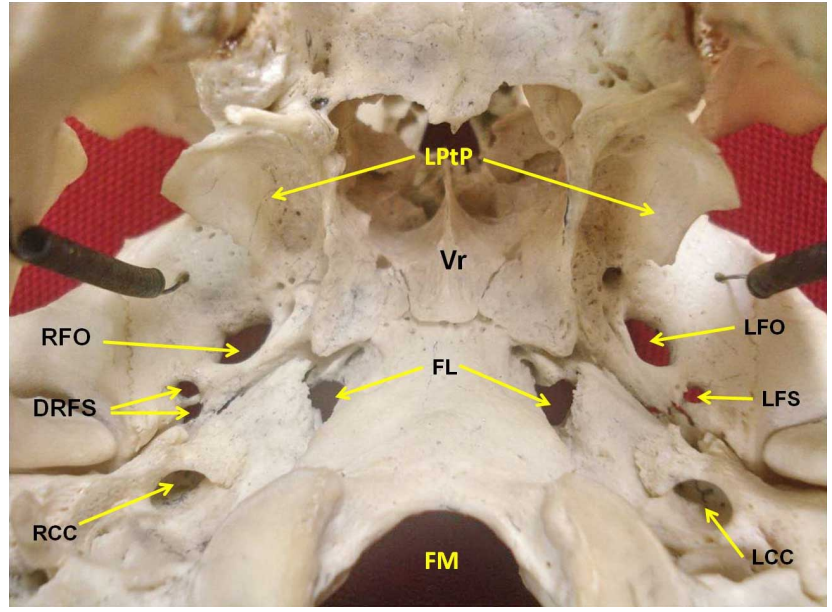

Fig. 6. Photograph of the base of the skull showing duplicated foramen spinosum on the right side . LPtP- Lateral Pterygoid Plate, Vr Vomer, FL - Foramen Lacerum, LFO - Left Foramen Ovale , LFS Left Foramen Spinosum, LCC - Left Carotid Canal, RCC - Right Carotid Canal, DRFS - Duplicated Right Foramen Spinosum, RFO Right Foramen Ovale, FM - Foramen Magnum.

ossified pterygospinous (ligament of Civinini) and pterygoalar (ligament of Hyrtl) ligaments divide the foramen ovale into two compartments. They concluded that such bony obstructions could interfere with transcutaneous needle placement into the foramen ovale. Similarly, Ray et al. in their study on anatomic variations of foramen ovale also reported a spine on the margin of the oval foramen in 3 cases, ( 2 left, 1 right) and 2 sides (1 left, 1 right) sides they found a bridge like bony spur dividing the foramen ovale into two compartments. We also noticed a relatively short bony spicule from the medial margin of foramen ovale. Reymond et al., reported that in $4.5 \%$ of their cases, foramen ovale was divided into 2 or 3 compartments. On the other hand, Skrzat et al. (2006) on visual inspection of a dry adult human skull revealed the absence of a typical foramen ovale on the left side of the cranial base. They found that the foramen ovale was covered by an osseous lamina, which was continuous with the lateral pterygoid plate forming a wall of an apparent canal, which opened on the lateral side of the pterygoid process.

Various studies on the morphometry of foramina of the greater wings of sphenoid have also reported variations of the foramen spinosum. The earliest perfect ring-shaped formation of the foramen spinosum is observed in the 8th month after birth and the latest in 7 years after birth. In the present study, we observed three cases of variant foramen spinosum out of 25 skulls studied. As reported above, the foramen spinosum was confluent with the foramen ovale in one case. 
In the second case, the foramen spinosum was completely absent on the left side which is quite a rare anomaly. The absence of foramen spinosum may occur when the meningeal artery arises from ophthalmic artery instead of the maxillary artery or in cases of when this artery enters the cranial cavity via the foramen ovale. Sometimes the persistent stapedial artery courses through the tympanic cavity, between the crura of the stapes and enters the facial canal distal to the geniculate ganglion and enters the middle cranial fossa by the facial hiatus, the opening for the greater superficial petrosal nerve, and becomes the middle meningeal artery (Bergman, 2006). Lindblom (1936) in his roentgenographic study of the vascular channels of the skull found that the foramen spinosum was small or altogether absent in $0.4 \%$ cases. Wood-Jones (1931) also found that the foramen spinosum to be more or less incomplete in approximately $44 \%$ of their cases. Similarly Berge \& Bergman (2001) stated that the foramen spinosum was found to be unilateral in $1 / 100$ (1\%) skulls or $1 / 199(0.5 \%)$ of foramina examined with no evidence of assimilation with the foramen ovale. Ginsberg et al. (1994), also reported that the foramen spinosum may be hypoplastic or absent in a case of an aberrant middle meningeal artery. They found that the foramen spinosum was absent in four $(3.2 \%)$ patients. On the contrary, Osunwoke et al. (2010) which studied 87 dried human skulls from the southern Nigerian population failed to find a single skull with absence foramen spinosum.

The final variant observed in the present study was a duplication of right foramen spinosum in one of the skulls. (Figs. 5 and 6). It appears that a bony bar dividing it into anterior and posterior compartments. This may be the result of an early division of the middle meningeal artery into anterior and posterior divisions before entering into the foramen spinosum, Lindblom and Sondheimer also reported this variant.

In conclusion, this study is of clinical and anatomical significance to medical practitioners in cases of trigeminal neuralgia and in diagnosing any aneurysm or vascular lesions of the cranial cavity. This knowledge will be useful to neurosurgeons for the identification and preservation of the neurovascular structures when using approaches to the middle cranial fossa.

\section{ACKNOWLEDGEMENTS}

We are thankful to all technologists of our department especially Mr. Mohd Harissal Ismail, Mr. Mohd Aidi Azhari Mohamad and Norhana binti Rashid for their technical support in taking photographs.

KHAN, A. A.; ASARI, M. A. \& HASSAN, A. Variantes anatómicas de los forámenes oval y espinoso en cráneos humanos. Int. J. Morphol., 30(2):445-339, 2012.

RESUMEN: Los forámenes oval y espinoso son forámenes importantes del ala mayor del esfenoides. Variaciones normales en sus formas y tamaños son muy comunes y ampliamente estudiados. En el presente repórter, llevado a cabo en el Departamento de Anatomía de la Facultad de Ciencias Médicas, Universiti Sains Malaysia, fueron examinados en 25 cráneos humanos secos las variaciones anatómicas de los forámenes del ala mayor del esfenoides. Durante el estudio, se observaron algunas variaciones anatómicas de los forámenes oval y espinoso. En un cráneo, se observó un foramen oval anormalmente grande e irregular, que era confluente con el foramen espinoso. En el segundo cráneo, el foramen espinoso estaba ausente en el lado izquierdo y en el tercer cráneo se duplicó en el lado derecho. Estas variaciones son muy raras y pueden ser de importancia clínica y anatómica para neurocirujanos y médicos, en particular en casos de neuralgia del trigémino, detección diagnóstica de tumores vasculares y aneurismas.

PALABRAS CLAVE: Variación; Cráneo; Foramen; Esfenoides; Foramen oval; Foramen espinoso.

\section{REFERENCES}

Berge, J. K. \& Bergman, R. A. Variations in size and in symmetry of foramina of the human skull. Clin. Anat., 14(6):406-13, 2001.

Bergman, R. A. Illustrated Encyclopedia of Human Anatomic Variation: Opus V: Skeletal Systems: Cranium. Sphenoid Bone, 2006. Available in: http:// www.anatomyatlases.org/Anatomic Variants/ SkeletalSystem/Text/SphenoidBone.shtml
Chaurasia, B. D. BD Chaurasia's Human Anatomy: Regional and Applied, Dissection and Clinical. $4^{\text {th }}$ Edition. New Delhi, CBS Publishers and Distributors, 2004.

Ginsberg, L. E.; Pruett, S. W.; Chen, M. Y. \& Elster, A. D. Skull-base foramina of the middle cranial fossa: reassessment of normal variation with high-resolution CT. Am. J. Neuroradiol., 15(2):283-91, 1994. 
Kaplan, M.; Erol, F. S.; Ozveren, M. F.; Topsakal, C.; Sam, B. \& Tekdemir, I. Review of complications due to foramen ovale puncture. J. Clin. Neurosci., 14(6):563-8, 2007.

Lindblom, K. Roentgenographic study of vascular channels of skull with special reference to intracranial tumors and arteriovenous aneurysms. Acta Radiol., 30:1-146, 1936.

Osunwoke, E. A.; Mbadugha, C. C.; Orish, C. N.; Oghenemavwe, E. L. \& Ukah, C. J. A morphometric study of foramen ovale and foramen spinosum of the human sphenoid bone in the southern Nigerian population. J. Appl. Biosci., 26:1631-5, 2010.

Ray, B.; Gupta, N. \& Ghose, S. Anatomic variations of foramen ovale. Kathmandu Univ. Med. J., 3(1):64-8, 2005.

Reymond, J.; Charuta, A. \& Wysocki, J. The morphology and morphometry of the foramina of the greater wing of the human sphenoid bone. Folia Morphol., 64(3):18893, 2005.

Sinnatamby, C. S. Last's Anatomy: Regional and Applied. $10^{\text {th }}$ Edition. Edinburgh, Churchill Livingstone, 1999.

Skrzat, J.; Walocha, J.; Srodek, R. \& Nizankowska, A. An atypical position of the foramen ovale. Folia Morphol., 65(4):396-9, 2006.

Sondheimer, F. K. Basal foramina and canals. In: Newton, T. H. \& Potts, D. G. (Editors). Radiology of the skull and brain. St. Louis, Mosby, 1971. pp.287-308.

Standring, S. Gray's Anatomy; The Anatomical Basis of Clinical Practice. $39^{\text {th }}$ ed. London, Elsevier Churchill Livingstone, 2005. pp.462-3, 465-7.

Tubbs, R. S.; May, W. R. Jr.; Apaydin, N.; Shoja, M. M.; Shokouhi, G.; Loukas, M. \& Cohen-Gadol, A. A. Ossification of ligaments near the foramen ovale: an anatomic study with potential clinical significance regarding transcutaneous approaches to the skull base. Neurosurgery, 65(6 Suppl):60-4, 2009.

Wood-Jones, F. The non-metrical morphological characters of the skull as criteria for racial diagnosis. par 1: General discussion of the morphological characters employed in racial diagnosis. J. Anat., 65(Pt 2):179-95, 1931.

Yanagi, S. Developmental studies on the foramen rotundum, foramen ovale and foramen spinosum of the human sphenoid bone. Hokkaido Igaku Zasshi, 62(3):485-96, 1987.

\section{Correspondence to: Aaijaz Ahmed Khan Senior Lecturer, Department of Anatomy Universiti Sains Malaysia Kubang Kerian - 16150, Kelantan MALAYSIA}

Phone: 0060-9-7676080

Mobile: 0060179031662

Fax: 006097653370

\section{Email: aaijazk@gmail.com aaijaz@kb.usm.my}

Received: 20-09-2011

Accepted: 29-02-2012 